\title{
Protective Effects of Kamikihi-To, a Traditional Chinese Medicine, against Cerebral Ischemia, Hypoxia and Anoxia in Mice and Gerbils
}

\author{
Koji Nishizawa, Osamu Inoue, Yuji Saito and Akira Suzuki \\ Traditional Chinese Medicine Research Laboratories, Kanebo, Ltd., 5-90, Tomobuchi-cho I-chome, Miyakojima-ku, Osaka 534, Japan \\ Received April 30, 1993 Accepted December 18, 1993
}

\begin{abstract}
The protective effects of Kamikihi-To (KMK), a traditional Chinese medicine, against cerebral ischemia, hypoxia and anoxia were investigated with various experimental models in mice and gerbils. KMK $(2.0 \mathrm{~g} / \mathrm{kg} /$ day, p.o. for 5 days $)$ significantly prolonged the survival time of mice subjected to bilateral common carotid artery occlusion. KMK $(0.5$ and $2.0 \mathrm{~g} / \mathrm{kg} / \mathrm{day}, \mathrm{p} .0$. for 5 days $)$ also prolonged the survival time of mice injected with $N$-methyl-D-aspartic acid (NMDA: $80 \mathrm{mg} / \mathrm{kg}$, i.v.). Furthermore, KMK (in a diet containing $8 \%$ KMK given orally for 34 days) showed protective effects against delayed neuronal death in CA1 pyramidal cells in the gerbil hippocampus after transient forebrain ischemia. On the other hand, we failed to show any protective effects of KMK $(0.5-2.0 \mathrm{~g} / \mathrm{kg} /$ day, p.o. for 5 days) against normobaric hypoxia and $\mathrm{KCN}$-induced cytotoxic anoxia in mice. These results suggest that KMK may have protective effects against cerebral ischemic disorders, but not against severe hypoxic and anoxic disorders.
\end{abstract}

Keywords: Kamikihi-To, Ischemia, Anoxia, Hypoxia, $N$-Methyl-D-aspartic acid

Kamikihi-To (KMK, Chinese name: Jia-Wei-Gui-PiTang), a traditional Chinese medicine described in "NeiKe-Zhai-Yao" (1529 A.D.), has been used to treat neurosis, amnesia, anemia and some other diseases. In a previous study, we showed that KMK ameliorated both ethanol-induced and electroconvulsion-induced memory impairment in mice (1). KMK also antagonized memory deficits in the senescence-accelerated mouse (SAM), which is characterized by age-related deficits in learning performance (2). Egashira et al. (3) have reported that KMK activated some cholinergic biochemical markers in the brains of aged rats. These studies showed that KMK might affect neurological functions in the central nervous system.

The KMK prescription consists of the following 14 herbs: Astragalus, Ginseng, Atractylodes, Hoelen, Polygala, Jujube, Longan, Zizyphus, Angelica, Licorice, Ginger, Saussurea, Bupleurum and Gardenia (1). Various studies of KMK components have been reported. Astragalus includes GABA, which improves decreased cerebral circulation and metabolism $(4,5)$. Ginseng and Angelica inhibit platelet aggregation $(6,7)$. Polygala suppresses congestive edema (8). These studies suggest that KMK may have protective effects against cerebral ischemic disorders.
In the present study, we investigated the protective effects of KMK against cerebral ischemia induced by bilateral occlusion of the common carotid arteries and against $N$-methyl-D-aspartic acid (NMDA)-induced death in mice. NMDA is an agonist of the NMDA receptor which belongs to the glutamate receptor subclass and is associated with ischemia (9). We also evaluated the protective effects of KMK against normobaric hypoxia and $\mathrm{KCN}$-induced cytotoxic anoxia in mice. In a histological study, we investigated the protective effect of KMK against delayed neuronal death in CA1 pyramidal cells in the gerbil hippocampus after transient forebrain ischemia.

\section{MATERIALS AND METHODS}

\section{Animals \\ Male ddY mice (Japan SLC, Shizuoka) at 5-6 weeks of age; male ICR mice (Japan SLC) at 5-7 weeks of age; and male Mongolian gerbils (Seiwa Experimental Animals, Fukuoka), 9-week-old at the start of the experi- ment, were used. They were housed in a temperature- and humidity-controlled $\left(23 \pm 1{ }^{\circ} \mathrm{C}, 55 \pm 2 \%\right)$ room and given a standard diet and tap-water ad libitum before they were used in the experiments.}




\section{Drugs}

KMK is a spray-dried powder of a hot-water extract prepared (with 10 parts of water at $95-100^{\circ} \mathrm{C}$ for $1 \mathrm{hr}$, yield: approximately 19\%) from a mixture of the fourteen constituent herbs (1). To verify the quality of the KMK, the quantities of geniposide and glycyrrhizin, which are derived mainly from Gardenia and Licorice, respectively, are evaluated by HPLC.

The following compounds were obtained commercially: flunarizine dihydrochloride (Sigma, St. Louis, MO, USA), $N$-methyl-D-aspartic acid (NMDA, Sigma) and sodium pentobarbital (Nembutal; Abbott Laboratories, North Chicago, IL, USA).

NMDA was dissolved in saline and adjusted to $\mathrm{pH} 7$ by the addition of $1 \mathrm{~N} \mathrm{NaOH}$. The other drugs were dissolved or suspended in saline. The injection volume was $10 \mathrm{ml} / \mathrm{kg}$ body weight, and an equal volume of saline was administered to the control mice. The diet (CE-2) containing $8 \%$ KMK was provided by Japan Clea Co., Ltd., Tokyo.

\section{Permanent cerebral ischemia induced by occlusion of the common carotid arteries in mice}

The method used was similar to that described by Himori et al. (10). Under anesthesia with sodium thiopental $(30 \mathrm{mg} / \mathrm{kg}$, i.v.), the upper cervical region of the ICR mice was incised in the midline, and the left and right carotid arteries were exposed. A loose silk ligature for occlusion was placed around both carotid arteries. The ends of the loose ligature were exteriorized through the skin at the back of the neck by a needle. Two days after the surgery, the mice were subjected to permanent cerebral ischemia by pulling the ends of the exteriorized loose ligature. Mice that lost the righting reflex were selected for the experiments.

Animals received saline $(n=24), K M K$ at $0.5 \mathrm{~g} / \mathrm{kg}$ $(\mathrm{n}=10), \mathrm{KMK}$ at $1.0 \mathrm{~g} / \mathrm{kg}(\mathrm{n}=9)$, or $\mathrm{KMK}$ at $2.0 \mathrm{~g} / \mathrm{kg}$ $(n=8)$ orally once a day for 5 days. On the fifth day, the final administration of KMK was conducted $1 \mathrm{hr}$ before the cerebral ischemia described above. Flunarizine at a dose of $30 \mathrm{mg} / \mathrm{kg}$ (p.o.) was administered as a single dose $1 \mathrm{hr}$ before cerebral ischemia $(n=10)$. The survival time between the induction of ischemia and respiratory arrest (the last observable inspiratory movement) was determined for a maximum of $60 \mathrm{~min}$.

\section{NMDA-induced death in mice}

Male ddY mice were divided into a control group $(\mathrm{n}=24)$, KMK-treated groups $(0.5 \mathrm{~g} / \mathrm{kg}, 1.0 \mathrm{~g} / \mathrm{kg}, 2.0$ $\mathrm{g} / \mathrm{kg} ; \mathrm{n}=14 \mathrm{each})$ and a flunarizine-treated group $(\mathrm{n}=8)$. They received these drugs orally as in the permanent ischemia experiment. One hour after the final administration of drugs, NMDA $(80 \mathrm{mg} / \mathrm{kg} / 10 \mathrm{ml})$ was injected at a rate of $0.3 \mathrm{ml} / 10 \mathrm{sec}$ via a tail vein. The survival time from injection with NMDA to respiratory arrest was determined for a maximum of $180 \mathrm{sec}$.

\section{Measurement of neuron numbers in the hippocampal $C A 1$ region in gerbils 8 days after ischemia}

Male gerbils were divided into a sham-operation group $(n=6)$, a control group $(n=15)$, a KMK-treated group $(n=8)$ and a pentobarbital-treated group $(n=8)$. Animals in the KMK-treated group were given the diet containing $8 \%$ KMK from 25 days before to 8 days after ischemia was induced. The average KMK dosage given to the gerbils was approximately $9.6 \mathrm{~g} / \mathrm{kg} /$ day. Animals in the pentobarbital-treated group were administered sodium pentobarbital at a dose of $40 \mathrm{mg} / \mathrm{kg}$, intraperitoneally $30 \mathrm{~min}$ before ischemia. Each gerbil was lightly anesthetized with a mixture of $2 \%$ halothane, $70 \%$ nitrous oxide and $30 \%$ oxygen. Both common carotid arteries were exposed, and cerebral ischemia was produced by occlusion of these arteries with miniature aneurysm clips for $5 \mathrm{~min}$. The body temperatures of the gerbils were monitored with a rectal thermometer (MGA-III; Nihon Kohden, Tokyo). Rectal temperatures were maintained at $36.0-37.0^{\circ} \mathrm{C}$ with a warming mat and heating lamp during the operation and until the righting reflex reappeared.

On the eighth day after clip removal, the animals were perfused transcardially with heparinized saline followed by perfusion-fixation with a solution of formaldehyde/ acetic acid/methanol $(1: 1: 8)$. Their brains were promptly removed, divided into coronal sections (about $5-\mathrm{mm}$ thickness) and immersion-fixed in the above solution. After fixation for a few days, each tissue block was dehydrated in a series of ethanol $(70-100 \%)$ and xylene before being embedded in paraffin. Coronal sections containing the dorsal hippocampus, $5-\mu \mathrm{m}$ thickness, were stained with cresyl violet. The number of neurons per $1-\mathrm{mm}$ linear length of the stratum pyramidale in the hippocampal CA1 subfield was calculated by counting intact neurons under a microscope and measuring the total length of the CAl cell layer in each section. The average of the neuronal densities from each side was regarded as the neuronal cell density of each gerbil.

\section{Normobaric hypoxia in mice}

Male ddY mice were divided into a control group $(\mathrm{n}=15)$, KMK treated groups $(0.5 \mathrm{~g} / \mathrm{kg}, 1.0 \mathrm{~g} / \mathrm{kg}, 2.0$ $\mathrm{g} / \mathrm{kg} ; \mathrm{n}=8 \mathrm{each}$ ), and a flunarizine-treated group $(\mathrm{n}=7)$. They received these drugs orally as in the permanent ischemia experiment. One hour after the final administration of drugs, the mice were placed in a plastic container $(30 \times 30 \times 30 \mathrm{~cm})$ continuously flushed with $100 \%$ nitrogen gas. The survival time from the induction of hypoxia to respiratory arrest was determined. 
Cytotoxic anoxia induced by $K C N$ in mice

Male ddY mice were divided into a control group $(\mathrm{n}=16), \mathrm{KMK}$-treated groups $(0.5 \mathrm{~g} / \mathrm{kg}, \mathrm{n}=10 ; 1.0 \mathrm{~g} / \mathrm{kg}$, $\mathrm{n}=10 ; 2.0 \mathrm{~g} / \mathrm{kg}, \mathrm{n}=9$ ), and a flunarizine-treated group $(n=7)$. They received these drugs orally as in the permanent ischemia experiment. One hour after the final administration of drugs, $\mathrm{KCN}(3 \mathrm{mg} / \mathrm{kg} / 10 \mathrm{ml})$ was injected at a rate of $0.3 \mathrm{ml} / 10 \mathrm{sec}$ via a tail vein. The survival time from injection of $\mathrm{KCN}$ to respiratory arrest was determined.

\section{Statistics}

The Mann-Whitney $U$-test was used to analyze the survival time following permanent ischemia and NMDA injection in mice and the number of neurons in gerbils. For analysis of the survival time after $\mathrm{N}_{2}$ - or KCN-treatment in mice, analysis of variance followed by Dunnett's multiple comparison test was used.

\section{RESULTS}

Effects of KMK on permanent ischemia induced by occlusion of the common carotid arteries in mice

The effects of KMK on permanent ischemia are shown in Fig. 1. The average survival time in the ischemic control animals was $25.3 \pm 4.5 \mathrm{~min}$. KMK prolonged the survival time in a dose-dependent manner. KMK at a dose of $2.0 \mathrm{~g} / \mathrm{kg}, \mathrm{p} . \mathrm{o}$. prolonged the survival time significantly in ischemic mice. Flunarizine also prolonged the survival time.

\section{Effects of KMK on NMDA-induced death in mice}

The effects of KMK on NMDA-induced death are shown in Fig. 2. The survival time after NMDA administration for the control group was $103.8 \pm 8.5 \mathrm{sec}$. KMK at doses of 0.5 and $2.0 \mathrm{~g} / \mathrm{kg}$ significantly prolonged the survival time after NMDA administration, but this effect was not dose-dependent. Flunarizine also prolonged the survival time of mice injected with NMDA.

\section{Effects of KMK on histological damage due to ischemia in} the gerbil hippocampus

Neuronal densities in each group are shown in Fig. 3, and representative photomicrographs of the hippocampal CA1 subfield are shown in Fig. 4. The number of neurons in the CA1 sector of the hippocampus for the sham-operation group was $188 \pm 3$ neurons $/ \mathrm{mm}$. In the ischemic control group, this decreased to $25 \pm 10$ neurons $/ \mathrm{mm}$. KMK significantly prevented the reduction in the number of surviving neurons $(47 \pm 25$ neurons $/ \mathrm{mm})$. Pentobarbital at $40 \mathrm{mg} / \mathrm{kg}$, i.p. also prevented the decrease in the number of neurons $(75 \pm 22$ neurons $/ \mathrm{mm})$.

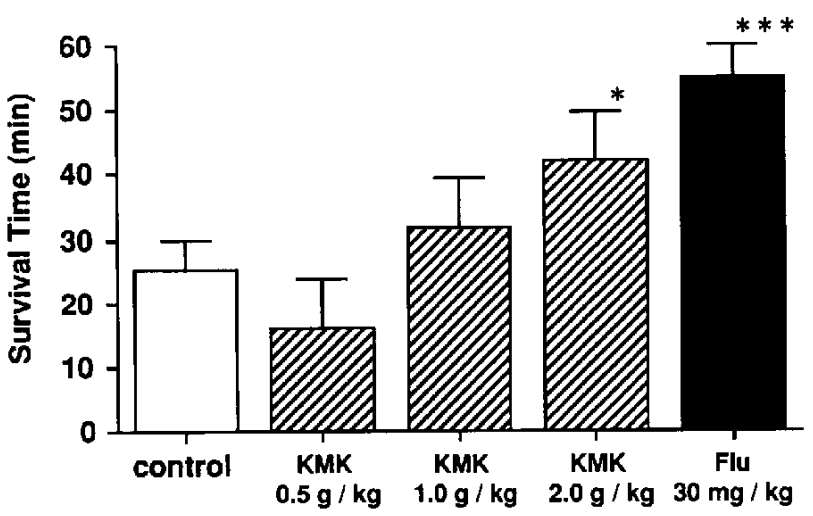

Fig. 1. Effect of KMK on the survival time of mice subjected to cerebral ischemia. Each value represents the mean \pm S.E.M.; control, $\mathrm{N}=24 ; \mathrm{KMK}, 0.5 \mathrm{~g} / \mathrm{kg}, \mathrm{N}=10 ; \mathrm{KMK}, 1.0 \mathrm{~g} / \mathrm{kg}, \mathrm{N}=9 ; \mathrm{KMK}$, $2.0 \mathrm{~g} / \mathrm{kg}, \mathrm{N}=8$; Flu: flunarizine, $30 \mathrm{mg} / \mathrm{kg}, \mathrm{N}=10$. ${ }^{*} \mathrm{P}<0.05$, ${ }^{* * *} \mathbf{P}<0.001$ vs. control (Mann-Whitney $U$-test).

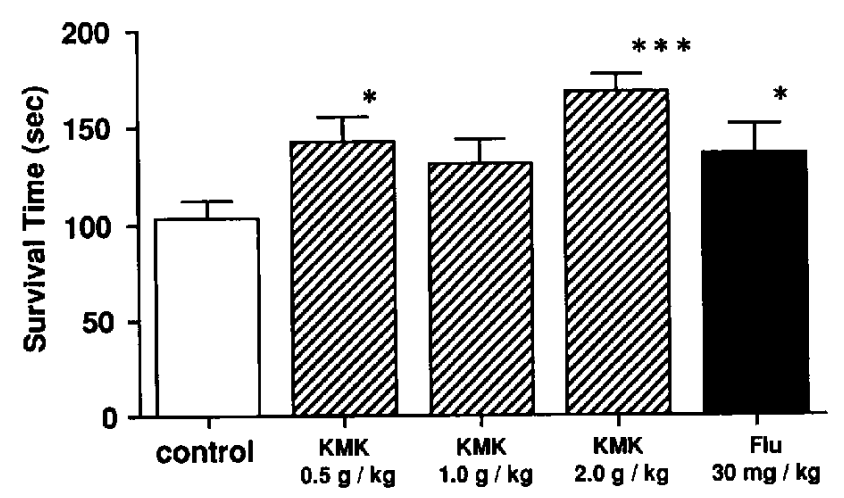

Fig. 2. Effect of KMK on the survival time of mice subjected to NMDA injection. Each value represents the mean \pm S.E.M.; control, $\mathrm{N}=24 ; \mathrm{KMK}, 0.5 \mathrm{~g} / \mathrm{kg}, \mathrm{N}=14 ; \mathrm{KMK}, 1.0 \mathrm{~g} / \mathrm{kg}, \mathrm{N}=14 ; \mathrm{KMK}$, $2.0 \mathrm{~g} / \mathrm{kg}, \mathrm{N}=14$; Flu: flunarizine, $30 \mathrm{mg} / \mathrm{kg}, \mathrm{N}=8 .{ }^{*} \mathrm{P}<0.05$, ${ }^{* * *} \mathrm{P}<\mathbf{0 . 0 0 1}$ vs. control (Mann-Whitney $U$-test).

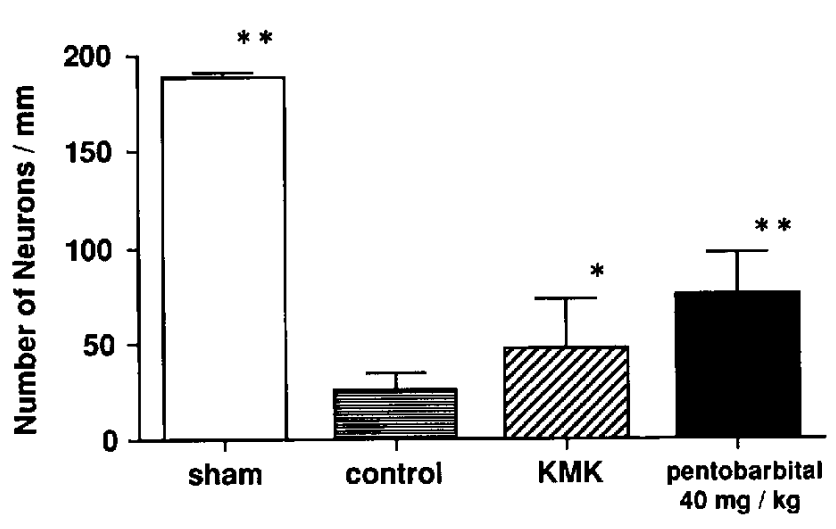

Fig. 3. Effect of KMK on neuronal damage of hippocampal CA1 neurons in gerbils subjected to ischemia. Each value represents the mean \pm S.E.M.; sham, $\mathrm{N}=6$; control, $\mathrm{N}=15$; $\mathrm{KMK}, \mathrm{N}=8$; pentobarbital, $40 \mathrm{mg} / \mathrm{kg}, \mathrm{N}=8 .{ }^{*} \mathrm{P}<0.05,{ }^{* *} \mathrm{P}<0.01$ vs. control (Mann-Whitney U-test). 

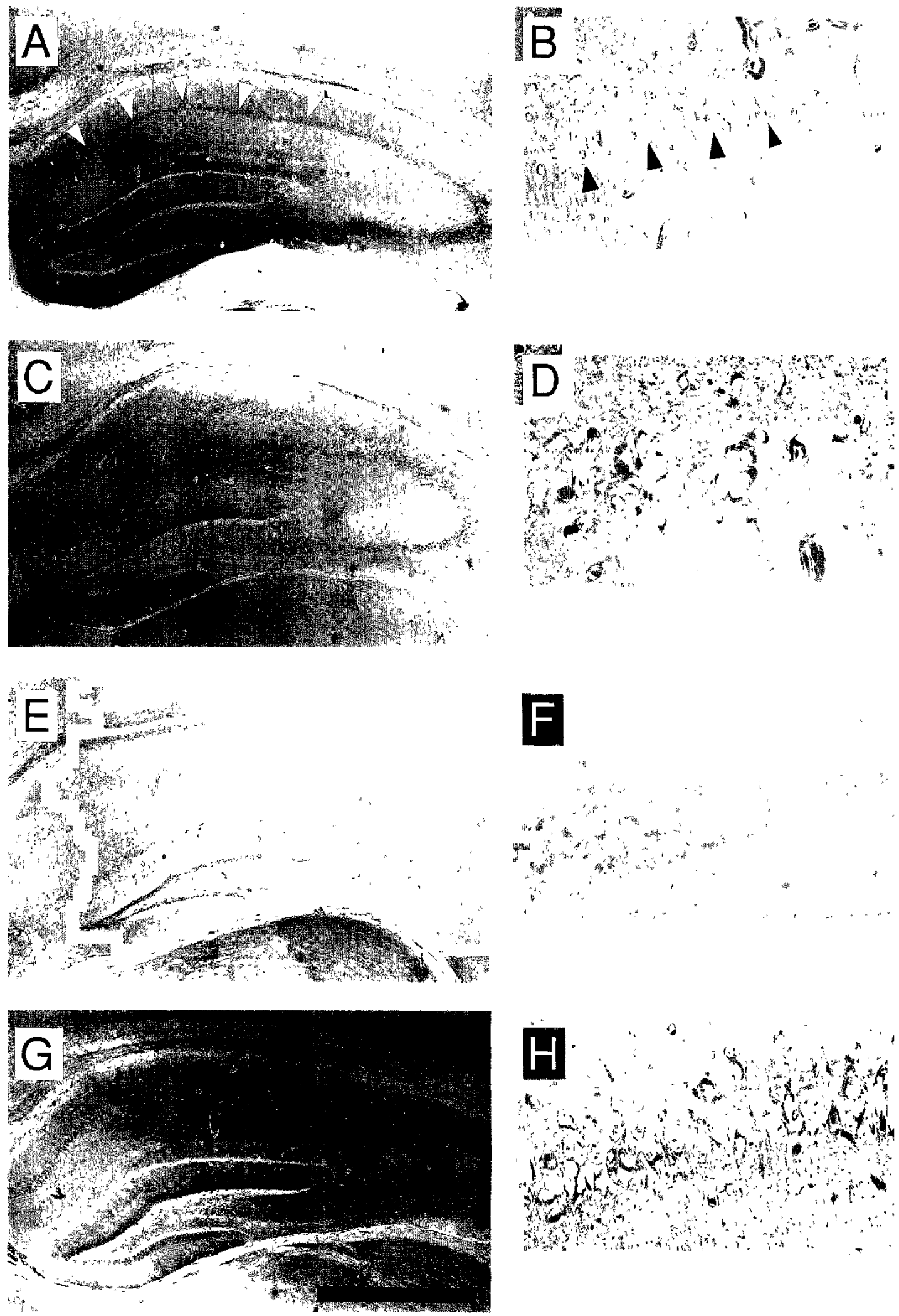

Fig. 4. Effect of KMK on histological damage due to ischemia in gerbil hippocampus. Photomicrographs of hippocampal CA1 sectors of gerbils taken 8 days after $5 \mathrm{~min}$ of bilateral common carotid artery occlusion. A and B: Photomicrographs of hippocampal CA1 sector (arrowheads) in a sham-operation gerbil. C and D: Photomicrographs of CA1 hippocampal sector in a normal diet treated gerbil. $\mathrm{E}$ and F: Photomicrographs of CA1 hippocampal sector in a KMK diet-treated gerbil. G and $\mathrm{H}$ : Photomicrographs of CA1 hippocampal sector in a pentobarbital-treated gerbil. Low-power calibration bar (left), $1 \mathrm{~mm}$; Highpower calibration bar (right), $100 \mu \mathrm{m}$. 
Table 1. Effect of KMK on normobaric hypoxia induced by $\mathrm{N}_{2}$ in mice

\begin{tabular}{lrrl}
\hline Drugs & & $\mathrm{N}$ & Survival time (sec) \\
\hline Control & & 15 & $20.7 \pm 0.8$ \\
$\mathrm{KMK}$ & $0.5 \mathrm{~g} / \mathrm{kg}$ & 8 & $24.0 \pm 1.8$ \\
& $1.0 \mathrm{~g} / \mathrm{kg}$ & 8 & $21.8 \pm 1.0$ \\
& $2.0 \mathrm{~g} / \mathrm{kg}$ & 8 & $23.0 \pm 1.3$ \\
Flunarizine & $30 \mathrm{mg} / \mathrm{kg}$ & 7 & $26.1 \pm 1.2^{* *}$ \\
\hline
\end{tabular}

Each value represents the mean \pm S.E.M. ${ }^{* *} \mathrm{P}<0.01$ vs. control (Dunnett's multiple comparison test).

Table 2. Effect of KMK on cytotoxic anoxia induced by $\mathrm{KCN}$ in mice

\begin{tabular}{lrcc}
\hline Drugs & & $\mathrm{N}$ & Survival time (sec) \\
\hline Control & & 16 & $29.0 \pm 3.4$ \\
KMK & $0.5 \mathrm{~g} / \mathrm{kg}$ & 10 & $34.5 \pm 2.5$ \\
& $1.0 \mathrm{~g} / \mathrm{kg}$ & 10 & $31.8 \pm 1.6$ \\
& $2.0 \mathrm{~g} / \mathrm{kg}$ & 9 & $35.1 \pm 3.9$ \\
Flunarizine & $30 \mathrm{mg} / \mathrm{kg}$ & 7 & $51.1 \pm 6.4^{* *}$ \\
\hline
\end{tabular}

Each value represents the mean \pm S.E.M. ${ }^{* *} \mathrm{P}<0.01$ vs. control (Dunnett's multiple comparison test).

\section{Effects of KMK on normobaric hypoxia in mice}

Mice exposed to hypoxia suffered convulsive seizures, followed by death due to respiratory failure. The effect of KMK on normobaric hypoxia is shown in Table 1. KMK had no effect in this experiment, whereas flunarizine at 30 $\mathrm{mg} / \mathrm{kg}$ significantly prolonged the survival time.

\section{Effects of KMK on cytotoxic anoxia induced by $K C N$ in mice}

An injection of $3 \mathrm{mg} / \mathrm{kg} \mathrm{KCN}$ produced convulsive seizures, followed by death due to respiratory failure. The effect of KMK on cytotoxic anoxia induced by $\mathrm{KCN}$ is shown in Table 2. KMK treatment did not affect the survival time of the mice. In contrast, flunarizine significantly prolonged the survival time.

\section{DISCUSSION}

In the present study, KMK prolonged the survival time of mice subjected to bilateral common carotid artery occlusion and mice injected with NMDA. Furthermore, KMK reduced histological damage to the gerbil hippocampus after transient forebrain ischemia. These findings suggest that KMK may have a protective effect against cerebral ischemia. It did not, however, affect the survival time of mice subjected to either normobaric hypoxia or cytotoxic anoxia.

Cerebral hypoxia, anoxia and ischemia produce various pathological phenomena and injuries. In hypoxia, the Krebs cycle stops, and only low levels of high-energybond phosphates are produced. Hence there is rapid glucose consumption and accumulation of unmetabolized lactic acid. Subsequently, glycolytic processes are arrested, and this is followed by an abrupt fall in the adenylate and phosphocreatinine pools (11). $\mathrm{KCN}$-induced cytotoxic anoxia occurs due to inhibition of cytochrome oxidase in the mitochondria, and the subsequent breakdown of cellular metabolism (12). In the ischemic situation, besides oxygen and glucose deprivation, there is also an acute lack of all blood nutrients and variable accumulation of metabolic and autolytic wastes (11). Thus, cerebral ischemia, normobaric hypoxia and $\mathrm{KCN}$-induced cytotoxic anoxia, as induced in the present experiments, are not identical disorders. In the normobaric hypoxia and cytotoxic anoxia models, high-energy-bond phosphate production is thought to be almost non-existent. In contrast, in the cerebral ischemic models in which KMK was effective, glycolytic and Krebs cycle processes are able to continue to a certain extent, because some oxygen and glucose can be transported to the cerebral tissues via the vertebral arteries. The unique profile of KMK in cerebral ischemic disorders might be due to these differences in each animal model. Various drugs (e.g., vasodilators (13), barbiturates (14), glutamate blockers (15), calcium antagonists (16), anticonvulsants (17), psycholeptics (18) and GABAergic agents (19)) have been reported to have protective effects against these disorders in animal models. However, it is difficult to determine the mechanism by which the protective effects of KMK occur because there are no drugs with a similar profile, as described below.

The normal clinical dose of KMK is approximately 0.1 $\mathrm{g} / \mathrm{kg} / \mathrm{day}$. The doses found to be effective in the present experiments in mice and gerbils, $2.0 \mathrm{~g} / \mathrm{kg} /$ day and 9.6 $\mathrm{g} / \mathrm{kg} / \mathrm{day}$, are about 20 times and 100 times higher than the normal clinical dose, respectively. This indicates that a high dose of KMK is needed to protect against ischemic disorders. These effective doses of KMK are not considered unusual because other drugs with a protective action against ischemic disorders also need to be given in high doses (e.g., the effective dose of flunarizine for KCNinduced death is $\mathbf{1 2 0}$ times higher than the normal clinical dose (16), and the dose of vinpocetine for ischemia is 80 times higher (13)).

The protective effects of flunarizine, a $\mathrm{Ca}^{2+}$ antagonist, against cerebral hypoxia-anoxia in mice and rats (16) and against ischemic injury in gerbils (20) have been reported previously. In the present experiments, flunarizine also showed protective effects against cerebral ischemia, 
hypoxia and anoxia. These effects of flunarizine are probably due to inhibition of $\mathrm{Ca}^{2+}$-induced vasoconstriction and more directly reduced $\mathrm{Ca}^{2+}$ entry into neurons (21). KMK did not protect against normobaric hypoxia and cytotoxic anoxia, although it did against the ischemia model. Therefore, the mechanism of action of KMK is different to that of flunarizine.

In the histological study, pentobarbital protected against neuronal death in gerbils after transient forebrain ischemia. Pentobarbital, an anesthetic, is known to decrease the excitability of the brain by facilitating the GABAergic system (19) and to reduce the metabolic demand by failure of energy metabolism (14). In our previous study, KMK at the doses used in this experiment did not produce sedation, muscle relaxation, prolongation of sleeping time by hexobarbital or hypothermia in mice (unpublished data, K. Nishizawa et al.), suggesting that the protective effects of KMK are not due to these anesthetic actions.

Some other traditional Chinese prescriptions have been known to have protective effects against cerebral ischemia. Zokumei-To has a protective effect against cerebral ischemia (22) and $\mathrm{KCN}$ anoxia, but no effect against normobaric hypoxia in mice (23). The protective effects of Zokumei-To are due to improvement of the cerebral circulation via vertebral blood flow (22). Shosaiko-To-GoKeishi-Ka-Syakuyaku-To has protective effects against hippocampal neuronal damage induced by a cobalt focus in the cerebral cortex and against cerebral ischemia in rats (24). The protective effects of Shosaiko-To-GoKeishi-Ka-Shyakuyaku-To are due to its inhibitory action on the synthesis of an abnormal protein initiated by excessive excitatory amino acid (24). The component herbs in these prescriptions are mostly different to those in KMK. The actions of these drugs are also different to those of KMK in the present experiments. These facts suggest that the mechanism of action of KMK must be different from those of these prescriptions.

KMK protected against delayed neuronal death in the gerbil hippocampal $\mathrm{CAl}$ region after transient forebrain ischemia. This area is thought to be particularly rich in NMDA receptors (25). Hypoxic-ischemic neuronal injury has been thought to be linked to excessive activation of postsynaptic glutamate receptors (9). Izumiyama and Kogure (15) have demonstrated that a glutamate blocker has a protective effect against delayed neuronal death after ischemia. Leander et al. (26) have reported that phencyclidine, a NMDA blocker, antagonized NMDA-induced death. KMK prevented NMDA-induced death, but did not affect pentylenetetrazol-induced death (unpublished data, K. Nishizawa et al.). This shows that KMK has a specific protective effect against NMDA-induced death. These findings indicate that the protective effects of KMK against delayed neuronal death and NMDA-induced death may be partially explained by inhibition of glutamate neurotoxicity.

In conclusion, we found that KMK has protective effects against cerebral ischemia and NMDA-induced death in mice and against delayed neuronal death in the gerbil hippocampus, but has no effect on severe disorders such as hypoxia and anoxia in mice under the experimental conditions used. The mechanism underlying the protective effect of KMK remains unknown and requires further study to elucidate its details. We proposed that these protective effects of KMK may be related to the pharmacological actions of KMK described in "Nei-Ke-Zhai$Y a o^{\prime}$, such as anti-neurosis, anti-amnesia or anti-anemia effects.

\section{REFERENCES}

1 Nishizawa K, Saito $\mathrm{H}$ and Nishiyama N: Effects of KamikihiTo, a traditional Chinese medicine, on learning and memory performance in mice. Phytotherapy Res 5, 97-102 (1991)

2 Nishizawa K, Saito $\mathrm{H}$ and Nishiyama N: Effects of KamikihiTo, a traditional Chinese medicine, on passive and conditioned avoidance performance impairment in senescence accelerated mouse (SAM). Jpn J Pharmacol 54, 375-382 (1990)

3 Egashira T, Sudo S, Murayama F, Kono T, Kudo Y, Goto S, Takayama $F$ and Yamanaka Y: Effects of kamikihi-to, a Chinese traditional medicine, on various cholinergic biochemical markers in the brains of aged rats. Folia Pharmacol Jpn 98, 273-281 (1991) (Abstr in English)

4 Hikino H, Funayama S and Endo K: Hypotensive principle of Astragalus and Hedysarum roots. Planta Med 30, 297-302 (1976)

5 Shibata T: Experimental study on cerebral circulation and metabolism at the acute brain injury with special emphasis on the effects of the substances concerning cerebral metabolism. Brain and Nerve 19, 231-240 (1967) (Abstr in English)

6 Morishita S, Saito T, Shoji M, Hirai Y and Tanaka A: Pharmacological studies of "Reiousan" which contains, bezoar and ginseng. Folia Pharmacol Jpn 91, 129-140 (1988) (Abstr in English)

7 Toriizuka K, Nishiyama P, Adachi I, Kawashiri N, Ueno M, Terasawa $\mathrm{K}$ and Horikoshi I: Isolation of a platelet aggregation inhibitor from Angelicae Radix. Chem Pharm Bull (Tokyo) 34, 5011 - 5015 (1986)

8 Yamahara J, Takagi Y, Sawada T, Fujimura H, Shirakawa K, Yoshikawa $\mathbf{M}$ and Kitagawa, I: Effects of crude drugs on congestive edema. Chem Pharm Bull (Tokyo) 27, 1464 - 1468 (1979)

9 Choi DW: Calcium-mediated neurotoxicity: relationship to specific channel types and role in ischemic damage. Trends Neurosci 11, 465-469 (1988)

10 Himori $N$, Watanabe $H$, Akaike $N$, Kurasawa $M$, Itoh $J$ and Tanaka Y: Cerebral ischemia model with conscious mice; Involvement of NMDA receptor activation and derangement of learning and memory ability. J Pharmacol Methods 23, 311-327 (1990)

11 Rossignol $\mathrm{P}$ and Ebigwei-Ibru M: Drugs against brain hypoxia. Trends Pharmacol Sci 1, 287-289 (1980) 
12 Ashton D, Reempts J and Wauquier A: Behavioural, electroencephalographic and histological study of the protective effect of etomidate against histotoxic dysoxia produced by cyanide. Arch Int Pharmacodyn Ther 254, 196-213 (1981)

13 Takeo S, Tanonaka K, Hirano T, Miyake $\mathrm{K}$ and Okamoto J: Cerebroprotective action of naftidrofuryl oxalate $\mathrm{I}$ : Prolongation of survival time and protection of cerebral energy metabolism in bilateral carotid artery-ligated mice. Folia Pharmacol Jpn 91, 267-273 (1988) (Abstr in English)

14 Hallmayer J, Hossmann KA and Mies G: Low dose of barbiturates for prevention of hippocampal lesions after brief ischemic episodes. Acta Neuropathol 68, 27-31 (1985)

15 Izumiyama K and Kogure K: Prevention of delayed neuronal death in gerbil hippocampus by ion channel blockers. Stroke 19, $1003-1007$ (1988)

16 Karasawa A, Kumada Y, Yamada K, Shuto K and Nakamizo N: Protective effect of flunarizine against cerebral hypoxia-anoxia in mice and rats. $J$ Pharmacobiodyn 5, 295-300 (1982)

17 Taft WC, Clifton GL, Blair RE and DeLorenzo RJ: Phenytoin protects against ischemia-produced neuronal cell death. Brain Res 483, 143-148 (1989)

18 Krieglstein $J$ and Heuer $H$ : On the usefulness of a model of acute hypoxia for testing cerebroprotective drugs. Arzneimittelforschung 36, 1568-1571 (1986)

19 Sternau LL, Lust WD, Ricci AJ and Ratcheson R: Role for $\gamma$ aminobutyric acid in selective vulnerability in gerbils. Stroke 20, $281-287$ (1989)
20 Alps BJ, Calder C, Hass WK and Wilson AD: Comparative protective effects of nicardipine, flunarizine, lidoflazine and nimodipine against ischaemic injury in the hippocampus of the Mongolian gerbil. Br J Pharmacol 93, 877-883 (1988)

21 Silverstein FS, Buchanan K, Hudson C and Johnston MV: Flunarizine limits hypoxia-ischemia induced morphologic injury in immature rat brain. Stroke 17, 477-482 (1986)

22 Goto K, Suekawa $\mathrm{M}$ and Hosoya E: Pharmacological study of TJ-8007 (Tsumura-Zokumeito) (II): Protective effect of TJ8007 against cerebral ischemia. Folia Pharmacol Jpn 93, 255-260 (1989) (Abstr in English)

23 Goto K, Suekawa M, Aburada $M$ and Hosoya E: Pharmacological study of TJ-8007 (Tsumura-Zokumeito) (I): Protective effects of TJ-8007 against anoxic brain damages. Folia Pharmacol Jpn 89, 355-363 (1987) (Abstr in English)

24 Goto K, Yamaura H, Shirasaka R and Oyama T: Inhibition of neuronal damage by the Japanese herbal medicine. I Tokyo Women's Medical College 63, 427-435 (1993) (Abstr in English)

25 Cotman CW, Monaghan, DT, Ottersen OP and Storm-Mathisen $\mathrm{J}$ : Anatomical organization of excitatory amino acid receptors and their pathways. Trends Neurosci 10, 273-280 (1987)

26 Leander JD, Lawson RR, Ornstein PL and Zimmerman DM: $N$-Methyl-D-aspartic acid-induced lethality in mice: selective antagonism by phencyclidine-like drugs. Brain Res 448, 115-120 (1988) 